\title{
Serial acquirer bidding: An empirical test of the learning hypothesis
}

\author{
Nihat Aktas ${ }^{1, *}$, Eric de Bodt ${ }^{2}$, and Richard Roll ${ }^{3}$ \\ ${ }^{1}$ EMLYON Business School, 23 av. Guy de Collongue, F-69130 Ecully, France \\ ${ }^{2}$ Univ. Lille Nord de France, \\ European Center for Corporate Control Studies, 1 place Déliot - BP381, F-59020 Lille, France \\ ${ }^{3}$ UCLA Anderson, Los Angeles, CA 90095-1481, United States
}

Draft: July 07, 2010

\begin{abstract}
Recent academic studies indicate that acquirers' cumulative abnormal returns (CAR) decline from deal to deal in acquisitions programs. Does this pattern suggest hubristic CEO behaviors are significant enough to influence average CAR patterns during acquisitions programs? An alternative explanation is CEO learning. This study therefore tests for learning using successive acquisitions of large U.S. public targets undertaken by U.S. acquirers. A dynamic framework reveals that both rational and hubristic CEOs take on average investor reactions to their previous deals into account and adjust their bidding behavior accordingly. These results are consistent with a learning hypothesis.
\end{abstract}

JEL classification: G34.

Keywords: Acquisitions program; Learning; Hubris; Bid premium

Acknowledgments

We are grateful to Jeffry Netter, an anonymous associate editor, and an anonymous referee for their constructive comments. We thank Luc Bauwens, Sandra Betton, Michael Brennan, Estelle Cantillon, Edith Ginglinger, Robert S. Hansen, Nancy Huyghebaert, Bertrand Jacquillat, Tanguy de Launois, Michel Levasseur, Frédéric Lobez, William L. Megginson, Christophe Perignon, Armin Schwienbacher, Evangelos Sekeris, Jean-Christophe Statnik, John Talbott, Walter Torous, Burcin Yurtoglu, and Rebecca Zarutskie, as well as participants at the NFA 2005 conference (Vancouver), the Hasselt 2006 Corporate Finance Day, the EFA 2007 conference (Ljubljana), the AFFI Paris Finance International 2009 meeting, the CORE Econometric seminar, the Dauphine CEREG seminar, the EMLYON Finance seminar, the ESC Lille Finance seminar, and the K.U.Leuven M\&A workshop for suggestions and insights. The second author acknowledges financial support from the University of Lille 2 (Finance, Banking and Accounting Department) and SKEMA Business School.

*Corresponding author. Tel.: +33 478337847 .

E-mail addresses: aktas@em-lyon.com (N. Aktas), eric.debodt@univ-lille2.fr (E. de Bodt), rroll@anderson.ucla.edu (R. Roll). 


\section{Introduction}

Several recent articles devoted to serial acquisitions note a commonly reported stylized fact, namely, the declining trend in acquirers' cumulative abnormal returns (CARs) during mergers and acquisitions (M\&A) programs (Fuller et al., 2002; Conn et al., 2004; Croci, 2005; Ahern, 2008; Ismail, 2008), even after controlling for CEO effects (Billett and Qian, 2008). One possible explanation is growing CEO hubris, as suggested by Conn et al. (2004), Ismail (2008), and Billett and Qian (2008). But declining CARs are also consistent with several other explanations, including optimal target picking (Ahern, 2008), time-varying investment opportunity sets (Klasa and Stegemoller, 2007), and budget-constrained acquirers. We believe the pattern also might reveal something more compatible with efficient resource allocation, that is, learning by CEOs during the process of making multiple acquisitions.

Specifically, CEO learning during an acquisition program is theoretically compatible with declining abnormal returns from deal to deal (Aktas, de Bodt and Roll, 2009; hereafter, ADR). The ADR model presumes that CEOs receive feedback from financial markets; i.e., investor reactions to their announcements, which provide signals that CEOs use to update their own beliefs about potential synergies with other targets. The market signals enable CEOs to gain experience and modify their bidding in subsequent transactions. The ADR model predicts that learning CEOs increase (decrease) their bidding aggressiveness from deal to deal after positive (negative) market reactions to previous acquisitions.

We test the implications of this learning hypothesis on CEO bidding with a sample of CEOs of U.S. firms who have undertaken two successive deals with sizeable U.S. public targets within a 12-month period between 1992 and 2007. The total number of deals ranges from 568 to 630, and the CEO sample ranges from 152 to 164 persons, ${ }^{1}$ depending on the measure of the bid premium that we use. The aggregate deal value in the sample ranges from $\$ 453$ to $\$ 589$ trillion. We focus on CEOs, not firms, because ADR consider learning at the CEO level (for similar approaches within the M\&A context, see Croci, 2005; Billett and Qian, 2008; for the effect of managers on firm policies and performance, see also

\footnotetext{
${ }^{1}$ Some CEOs in the sample completed sequences of two deals more than once.
} 
Bertrand and Schoar, 2003; Chang et al., forthcoming). In addition, this choice enables us to study the dynamic of the CEO bidding behavior and test empirical predictions specific to the learning hypothesis. Using an autoregressive approach, we model the relation between the bid premium for the current deal and investor reactions in the previous deal. With this autoregressive approach, we can study the channels through which investor reactions affect CEO bidding behavior, if any. We also consider the extent to which the relation between investor reactions and CEO bidding behavior is affected by CEO experience and hubris.

Our results are consistent with learning; CEOs appear to acknowledge the signals that investors send and dynamically adjust their bidding from deal to deal. This dynamic adjustment is economically significant: In reaction to a decrease of one standard deviation in abnormal returns after their previous deal announcement, CEOs reduce their bids by $4.27 \%$ in the subsequent deal. This shift corresponds to a bid premium percentage change of $-12 \%$ from one deal to the next. Our results also highlight that investor reactions mainly modify the persistence of the CEO bidding behavior from deal to deal, such that it decreases (increases) following negative (positive) signals. The experience of the CEO in deal making affects the learning process, and both rational and hubristic CEOs learn on average from market signals.

Our results also are robust across premium definitions. That is, we obtain comparable results using the abnormal return premium (Schwert, 1996), final offer premium (Officer, 2003), and four-week premium reported in the Thomson-Reuters SDC database. Our results do not seem driven by endogenous sample selection; we use Heckman's (1979) two-stage procedure to control for this potential bias (Li and Prabhala, 2007). However, Netter et al. (2010) uncover a different pattern of the global M\&A market activity in their sample of 250,000 deals in comparison to a sub-sample focusing on large transactions between listed firms; therefore, the composition of our M\&A samples (successive deals within a time period of 12-month on sizeable public U.S. targets) suggests the need for caution before generalizing the results to an overall CEO population. The learning process depends on the time period for identifying successive deals undertaken by a given CEO of a specific firm as well. In this respect, our results support 
Hayward's (2002) argument that very long or very short intervals between successive deals hamper learning.

We also recognize the wide-ranging research on bid premium determinants. Previous contributions have examined, inter alia, target size, target book-to-market ratio, target run up, toeholds, the acquirer's status (public or private), the means of payment (cash or stock), and the role of the termination agreement (for a review, see Eckbo, 2009). Our dynamic model of bidding adds two new dimensions though: (1) CEO bidding is persistent (CEOs who bid high continue to bid high, and those who bid low continue to do so), and (2) CEOs adjust their bidding to signals sent by investors after previous deals. The latter result reveals the importance of CEO learning in the M\&A setting.

Our study also complements two previous articles that provide evidence of learning from market reactions around M\&A activity. Luo (2005) shows that the probability of deal completion is a positive function of the market's reaction to the deal announcement. Kau et al. (2008) document that managers pay attention to the market when deciding whether to consummate deals. Our empirical design differs from theirs in that we focus on the bid premium, not the probability of deal completion, as the dependent variable. We use investor reactions to the CEO's previous, not concurrent, deal announcement as market signals. We also adopt an autoregressive framework to explain the bid premium of the current deal.

Our article also relates to broader literature on managerial learning from the information contained in stock prices. Several theoretical and empirical contributions emphasize the role of financial markets as important learning channels for corporate managers. Theoretical corporate finance literature argues that managers can learn from the information contained in stock prices about the prospects of their own firms (e.g., Dow and Gorton, 1997; Subrahmanyam and Titman, 1999). Chen et al. (2007) show empirically that the amount of private information in stock prices has a strong positive effect on the sensitivity of corporate investments to stock prices. These authors therefore conclude that "managers learn from the private information in stock price about their own firms' fundamentals and incorporate this information in the corporate investment decisions" (Chen et al., 2007, p. 619). 
The remainder of this article proceeds as follows: In Section 2, we briefly review recent contributions pertaining to corporate serial acquisitions, value creation effects, and acquirer bidding behavior. We then introduce an autoregressive model to test ADR's prediction. Section 3 describes the measures of the bid premium and market signal, the sample, and our empirical methods. The results in Section 4 lead into our summary and conclusions in Section 5 .

\section{Acquisitions programs and CEO bidding behavior}

2.1. Value effects of acquisitions programs

More than a quarter century ago, Schipper and Thompson (1983) emphasized the repetitive nature of acquisitions and showed that acquisitions program announcements can create value. These authors also introduced the concept of an acquisitions program anticipation effect. Market reactions to subsequent deal announcements do not represent the full value created but instead are revisions of previous investor anticipations. Fuller et al. (2002), Conn et al. (2004), Croci (2005), Ahern (2008), Ismail (2008), and Billett and Qian (2008) all find declining CAR trends during M\&A programs, which Conn et al. (2004), Ismail (2008), and Billett and Qian (2008) interpret as a sign of hubris, with the implicit assumption that hubris grows from deal to deal.

However, other authors provide alternative explanations. Fuller et al. (2002) assert that declining acquirer CAR for public targets results from offers made with stock, possibly due to their ownership dilution effect. With regard to private target acquisitions, they hypothesize that the declining trend in acquirer CAR reflects less efficient negotiation by bidders who engage in many quick acquisitions. Croci (2005) instead uses performance persistence measures borrowed from performance attribution literature to determine that neither performance persistence (i.e., good deals following good deals) nor performance reversals (bad deals following good deals) are statistically significant. Therefore, Croci (2005) concludes that CEOs neither possess superior target picking skills nor are systematically overconfident. Klasa and Stegemoller (2007) offer another argument: On the basis of the relationship between growth opportunities and M\&A sequences, they find that M\&A sequences correlate with expansions of the investment 
opportunity set. The negative acquirer CAR trend observed ex-post thus could reflect a declining investment opportunity set during the M\&A programs. Finally, Ahern (2008) develops a model of optimal target size choice by the acquirer, such that as acquirers grow larger, they tend to choose bigger targets in absolute size, though they are smaller in relative size, which induces declining returns from deal to deal. This finding is consistent with empirical evidence but has no implications regarding either hubris or diminishing opportunity sets.

\subsection{Determinants of takeover premiums}

Auction theory provides theoretical guidance for explorations of acquirer bidding, and related literature has introduced models of jump-bidding (Fishman, 1988), toeholds (Burkart, 1995; Bulow et al., 1999; Betton and Eckbo, 2000; Betton et al., 2009), overbidding as a consequence of the winner's curse (Roll, 1986), means of payment in the context of asymmetric information (Hansen, 1987; Fishman, 1989; Eckbo et al., 1990; Dasgupta and Tsui, 2004; DeMarzo et al., 2005), features of (formal or informal) auctions held by companies (Hansen, 2001), and M\&A waves (Rhodes-Kropf and Viswanathan, 2004).

Bid premiums are the direct output of the bidding behavior exhibited by acquirer CEOs. Existing literature documents a long list of bid premium determinants, as well illustrated by Betton et al.'s (2008) analysis of a sample of 4,889 control bids for U.S. targets during 1980-2002. The authors confirm the significant role of target size (i.e., the bigger the target, the lower the offer premium), the target book-tomarket ratio (i.e., targets with ratios higher than the industry median earn a higher offer premium), the target run up (i.e., the higher the run up, the higher the offer premium, which Schwert [1996] characterizes as markup pricing), the toehold (i.e., the higher the toehold, the lower the offer premium), the acquirer's status (i.e., public acquirers pay higher premiums), the deal type (i.e., premiums are lower for tender offers than for mergers), and the means of payment (i.e., cash deals are associated with higher premiums). Officer (2003) and Bates and Lemmon (2003) also study the role of termination agreements and show that premiums are higher in their presence. Some evidence indicates that a target CEO's entrenchment and 
power reduce takeover premiums (Hartzell et al., 2004; Moeller, 2005). ${ }^{2}$ To the best of our knowledge though, the dynamics of acquirer bidding and the impact of learning on premiums in the course of corporate serial acquisitions remain unexplored.

\subsection{CEO behaviors in the M\&A context}

Recent academic contributions stress the importance of a CEO's personal characteristics to explain firm decisions and performance (see, e.g., Bertrand and Schoar, 2003; Malmendier and Tate, 2008; Chang et al., forthcoming). In this respect, M\&A decisions are particularly well suited, because the resources in play are particularly important. According to Roll (1986), hubristic CEOs overestimate their capacity to create value when buying targets: They believe their valuation is right and the market does not reflect the full economic value of the combined firm. Hubris is therefore a cognitive bias that leads to irrational decision making in an uncertain situation. Uncertainty also emphasizes the potential added value of learning.

Many theories of learning appear in psychology research. According to Kolb (1984), experiential learning reflects learning by doing and is the process of knowledge creation through the transformative effects of experience. In this sense, hubris and learning are compatible: Repetitive acquisitions allow hubristic CEOs to learn by experience and adjust their valuation process and bidding behavior. Testing for learning therefore equates to testing for the presence of a relation between behavior and experience. Growing hubris may be a conceptual rival of the learning hypothesis, but if hubristic CEOs make increasingly irrational decisions, their ability to learn appears questionable. An empirical test of the learning hypothesis therefore must (1) pinpoint the relation between decision making and experience and (2) disentangle learning from growing hubris.

\footnotetext{
${ }^{2}$ Because several determinants are endogenous choice variables (e.g., means of payments, toehold, termination agreements), Eckbo (2009) emphasizes the need for caution with regard to the robustness of the reported results.
} 


\subsection{Learning and acquirer bidding behavior: The ADR model}

The theoretical model of CEO bidding during acquisitions programs proposed by ADR to explore the relations among learning, hubris, and CEO bidding behavior considers an underdiversified, risk-averse CEO who competes in the market for acquisitions, values potential synergies with possible targets, and then attempts to buy those targets, whether through competitive bidding or direct bargaining. When evaluating potential synergies, the CEO maximizes personal utility and faces a conundrum: If the valuation and offering price are too low, the takeover attempt will probably fail, but if the valuation and price are too high, the CEO risks some form of penalty imposed by angry shareholders in response to disappointing ex-post results.

Learning enters the ADR model as Bayesian updating. That is, investor reactions to past deal announcements represent signals received by the CEO (the source of CEO experience), which he or she uses to assess the adequacy of the valuation and bidding behavior. Using standard Bayesian inference to model the relation between CEO decision making and experience, ADR show that for a constant level of synergies with the target, ${ }^{3}$ rational CEOs increase their bidding aggressiveness after value-creating deals but behave more conservatively after value-destroying deals. We summarize these results in Equation (1):

$$
\frac{\partial \beta_{d}^{*}\left(v_{d}^{*}\left(S C A R_{d-1}\right)\right)}{\partial S C A R_{d-1}}=\frac{\partial \beta_{d}^{*}\left(v_{d}^{*}\right)}{\partial v_{d}^{*}} \times \frac{\partial v_{d}^{*}\left(S C A R_{d-1}\right)}{\partial S C A R_{d-1}}
$$

where $\beta_{d}^{*}$ is the equilibrium bid; $v_{d}^{*}$ is the CEO's risk-adjusted valuation of the target obtained by maximizing the CEO's utility; SCAR, or the acquirer's standardized cumulative abnormal returns around the announcement date, is the signal sent by investors; and $d$ and $d-1$ designate the current and previous deals undertaken by the CEO, respectively. The essential features of the ADR model thus are as follows:

- $\partial \beta_{d}^{*}\left(v_{d}^{*}\right) / \partial v_{d}^{*}>0$, because in equilibrium, CEO bidding increases with the CEO's risk-adjusted valuation of the target. This result is standard in auction theory.

\footnotetext{
${ }^{3}$ To isolate the effect of learning on abnormal returns, ADR assume that the investment opportunity set is constant during the acquisition program sequence.
} 
- $\quad \partial v_{d}^{*}\left(S C A R_{d-1}\right) / \partial S C A R_{d-1}>0$, because the CEO's risk-adjusted valuation is a positive function of investor reactions to the previous deal announcement. This point is a consequence of the Bayesian updating process (i.e., market signals improve the precision of the synergies valuation) and captures the positive relation between valuation creation and experience in deal making.

- $\quad \partial \beta_{d}^{*}\left(v_{d}^{*}\left(S C A R_{d-1}\right)\right) / \partial S C A R_{d-1}$ is positive. For a given level of expected synergies, the CEO's riskadjusted valuation of the target increases, and this learning effect translates into more aggressive bidding.

A direct test of the theoretical implications of the ADR model therefore is as follows:

$$
\text { Premium }_{d}=\alpha_{0}+\alpha_{1} S C A R_{d-1}+\varepsilon_{d},
$$

where Premium $_{d}$ is the bid premium for the current deal (the empirical counterpart of $\beta_{d}^{*}$ in the ADR model); SCAR, or the acquirer's standardized cumulative abnormal returns around the announcement date, is the signal sent by investors; and $d$ and $d-1$ designate the CEO's current and previous deals, respectively. (For brevity, we suppress the individual CEO designator in Equation (2).) This regression suffers from two shortcomings. First, potential synergies with targets vary from deal to deal and must be controlled for by including variables that capture the main deal and target characteristics. Second, as highlighted in Equation (1), the relation between the previous deal's $S C A R$ and the current deal's premium depends on the CEO's utility function. This second issue can be solved classically by using a fixed effects model that controls for CEO unobservable characteristics, leading to the following regression equation:

$$
\text { Premium }_{d}=\alpha_{i}+\alpha_{1} \text { SCAR }_{d-1}+\beta^{\prime} \text { Control }_{d}+\varepsilon_{d}
$$

where $\alpha_{i}$ are CEO fixed effects, and Control is a vector of control variables commonly employed in M\&A literature to predict target premiums. The regression model defined in Equation (3) raises further issues though. First, the CEO's utility function incorporates risk aversion, a time-varying latent factor. This time 
variation is ignored by the fixed effect models. Second, and perhaps even more important, if learning is constant through time, it may be absorbed by the fixed effect constants $\left(\alpha_{i}\right)$ and not be observable. ${ }^{4}$

To solve these issues, we test whether CEOs learn from deal to deal by using a dynamic regression equation to model their bidding behavior. The general form of this specification is:

$$
\begin{aligned}
\text { Premium }_{d}= & \alpha_{0}+\alpha_{1} \text { Premium }_{d-1}+\alpha_{2} \text { SCAR }_{d-1} \\
& \left.+\alpha_{3} \text { Premium }_{d-1} \times S C A R_{d-1}\right)+\beta^{\prime} \text { Control }_{d}+\varepsilon_{d} .
\end{aligned}
$$

The autoregressive term (Premium $\left._{d-1}\right)$ controls for the CEO effect, such that we expect the bidding behavior of a CEO to relate to his or her past bidding behavior (i.e., whether the CEO is initially hubristic or rational, one who bids high tends to continue to bid high, and vice versa). Moreover, we expect $\alpha_{1}$ to fall between 0 and 1 . A value of $\alpha_{1}$ below 0 would lead to negative premium. A value of $\alpha_{1}$ greater than 1 would indicate explosive bidding behavior. For example, if the bid premium for the initial deal is around $40 \%$ (a typical figure for offers on public targets), and the $\alpha_{1}$ coefficient is equal to 1.1 (slightly above 1 ), the bid premium at the tenth deal would already be greater than 94\% (assuming 0 SCAR from deal to deal). Conceivably, explosive bidding behavior, $\alpha_{1}>1$, might be generated by growing hubris, but such growth cannot be sustained over the long run. Finally, we include in this dynamic model an interaction term between the autoregressive term Premium $_{d-1}$ and the SCAR of the previous deal to study the effect of investor reactions to past deal announcements on the persistence of CEO bidding behavior.

According to the learning hypothesis, investor reactions should influence the bid premium directly or through the persistence coefficient. Specifically, we expect:

- $\alpha_{2}>0$, such that when investors react favorably to the previous deal, the CEO is reassured and becomes more aggressive, whereas when the previous deal is greeted unfavorably by investors, the CEO becomes less aggressive.

- $\quad \alpha_{3}>0$, because the extent to which past bidding behaviors influence the CEO's current bidding (persistence) should be a function of investor reactions to past deal announcements. A favorable

\footnotetext{
${ }^{4} \mathrm{~A}$ third issue relates to the power of fixed effects models. In practice, only a few deals are observed by CEOs, so the number of degrees of freedom tends to be low, which hampers the model's capacity to reject the null hypothesis of no learning.
} 
investor reaction to the previous deal announcement (positive $S C A R$ ) should lead the CEO to replicate past bidding behavior more closely (bidding behavior is more persistent). In the case of negative investor reactions to the previous deal announcement, a learning CEO should question previous choices and adopt less persistent (more conservative) bidding behavior.

The learning hypothesis also suggests a positive marginal effect of SCAR on bid premium, $\left(\alpha_{2}+\alpha_{3}\right.$ Premium $\left._{d-1}\right)>0$, because positive signals sent by investors should give the CEO more confidence (make the CEO less risk averse, according to ADR), whereas negative signals should make the CEO more conservative. Testing whether the marginal effect of SCAR on the bid premium is positive in Equation (4) is the counterpart of testing the positive relation between SCAR for the previous deal and bid premium for the current deal (coefficient $\alpha_{1}$ ) in Equation (3).

Finally, our dynamic regression approach provides a clear test of the learning hypothesis in comparison with growing hubris, because $\alpha_{1}>1$ is incompatible with learning but predicted by growing hubris. Alternative arguments about the pattern of value creation from deal to deal offer no predictions about the persistence of bidding behavior. In particular, Ahern's (2008) optimal target size choice argument indicates nothing about the relation between CEO bidding and investor reactions to previous deal announcements. Klasa and Stegemoller's (2007) time-varying investment opportunity set theory also is silent with respect to the persistence of CEO bidding behavior.

\section{Variables, sample, and empirical methods}

\subsection{Measures of bid premium and market signal}

Bid premium. The main observable output of CEO bidding is the bid premium, for which we examine three different measures: the abnormal return (AR) premium (Schwert, 1996), the final offer premium (Officer, 2003), and the four-week offer premium. ${ }^{5}$

\footnotetext{
${ }^{5}$ We compute the two offer premiums using information from the Thomson-Reuters SDC database.
} 
The AR premium equals the target cumulative abnormal returns from day -42 to the delisting date or to day +126 relative to the announcement date. Daily abnormal returns are computed with the Beta-one model, which subtracts the daily market portfolio return from the daily return of each company. (Using the standard market model does not alter the results.) The market portfolio is proxied by the value-weighted CRSP index, and stock prices come from CRSP.

The final offer premium corresponds to the final price offered per stock (field HOSTPR in the SDC database), deflated by the target stock price 42 days before the announcement date, or $\left(p_{f i n} / p_{-42}\right)-1$, where $p_{\text {fin }}$ is the final offer price and $p_{-42}$ is the target stock price adjusted for splits and dividends.

The four-week offer premium corresponds to the four-week bid premium as a percentage, reported by SDC (field PREM4WK). It is the premium of the offer price to the target closing stock price four weeks prior to the original announcement date.

Market signal. We use the standardized cumulative abnormal return (SCAR) of the acquirer around the previous deal announcement as a proxy for signals sent by investors. Analogous to the AR premium, it is computed with the Beta-one model (Fuller et al., 2002). The event window spans day -5 to day +5 , relative to the announcement date. ${ }^{6}$ To capture the relative strength of the signal sent by investors, SCAR is standardized by dividing the event window CAR by a standard deviation from daily abnormal returns over day -242 to day -43 , relative to the announcement date.

\subsection{Sample description}

The analysis focuses on CEO-firm couples, that is, an individual CEO at a particular firm. An observation is defined as two successive deals completed by the same CEO-firm within a certain time period. A sequence starts with the first deal by the CEO of a particular firm and ends after the second deal announced within 12 months, relative to the month of the first deal. When a sequence ends, another

\footnotetext{
${ }^{6}$ We have also used a $[-1,+1]$ event window relative to the announcement date to estimate $S C A R$. Our results are robust to the choice of the event window length. These results are available on request.
} 
sequence starts with the next deal of the CEO-firm, and so forth. We refer to the CEO-firm hereafter by the generic term "CEO."

To form the sample, we first extract from the Thomson-Reuters SDC database the 5,912 M\&A transactions that satisfy the following criteria:

1. The deal is announced during the period 1992-2007;

2. The deal status is completed;

3. Both the target and the bidder are listed U.S. firms;

4. The deal size is greater than $\$ 1$ million and equal to at least $1 \%$ of the acquirer's market value (see Masulis et al., 2007); and

5. The necessary information is available on CRSP for both the acquirer and target (i.e., prices, number of shares, and returns).

There are 5,902 individual CEOs in the Compustat ExecuComp database during the period 1992-2007. Using this list of CEOs and the initial sample of M\&As, we identify all instances of a CEO announcing two successive acquisitions during a time period not exceeding 12 months. (We also report results using 6and 24-month time frames.)

The final sample size depends on the availability of the AR premium, the final offer premium, or the four-week premium. ${ }^{7}$ For the AR premium, our sample includes 315 CEO-firm couples that made two successive acquisitions within 12 months, involving 164 different CEOs. When the final offer premium is the focus, our sample includes 296 sequences of two deals undertaken by 156 unique CEOs, and the fourweek premium sample includes 284 sequences by 152 unique CEOs. The median deal value falls between $\$ 369$ and \$383 million, depending on the definition of the bid premium, and the corresponding average deal value is $\$ 1.8-\$ 2$ billion (which indicates a few large transactions). These figures highlight that our empirical analysis bears on large repetitive acquisitions of public targets completed by a given CEO. We

\footnotetext{
${ }^{7}$ In the multivariate analyses, the availability of some control variables induces further reductions in sample size.
} 
study in the robustness checks section whether the obtained results can be generalized to the whole population of CEOs (see Section 4.4).

Table 1 reports the averages and medians of the three bid premium measures and acquirer announcement CARs for the two successive transactions undertaken by a given CEO within 12 months. The average AR premium is 32.33\%, whereas Schwert (1996) and Gaspar et al. (2005) report average AR premiums of $23 \%$ (1975-1991) and 23.4\% (1990-1999), respectively. But their samples include both successful and unsuccessful transactions, whereas our sample is limited to completed transactions, and this distinction may explain the difference. The average final offer premium is $45.02 \%$ in our sample, slightly lower than the average premiums of $48.65 \%$ and $46.10 \%$ reported by Officer (2003) and Betton et al. (2009), respectively. The average four-week premium is $40.82 \%$ in our sample. Datta et al. (2001) and Boone and Mulherin (2007) report similar magnitudes for samples of 628 takeovers (1993-1998) and 308 takeovers (1989-1999), respectively.

Consistent with prior literature, the average AR premium in our sample is substantially lower than the averages obtained with the two SDC premiums, because the AR premium reflects not the only the offer price but also the likelihood of a completed acquisition (Eckbo, 2009). Because average premiums differ substantially from one measure to another, we test the robustness of our results to the alternative bid premium definitions.

Finally, the current bid premium (deal $d$ ) is on average lower than the previous premium (deal $d-1)$, but the difference is not statistically significant, regardless of the premium's definition.

Panel D of Table 1 captures the declining CAR trend from deal to deal: The current deal mean CAR is $-1.10 \%$, whereas previous deal mean CAR is $-0.12 \%$. The declining trend is however only statistically significant with the variable SCAR.

We also include in Table 1 the fraction of negative premiums and acquirer CARs for the current and previous deals. The fraction of negative premiums is larger for the abnormal return-based premium (13.33\% of previous deal premiums are negative) compared with the premium measures from the SDC database (between $2.82 \%$ and $5.74 \%$ of previous deal premiums are negative). Fifty-five percent of the 
previous acquisition firm CARs are negative; that is, negative market signals exceed positive market signals, though only slightly.

\subsection{Empirical methods}

To avoid feedback effects, all financial ratios are measured at the year end prior to the acquisition announcement. Financial ratios frequently exhibit large outliers (especially when the book value of equity is the denominator), so all ratios are winsorized at the 1st and 99th percentiles.

We adopt the Fama-French 49-industry classification scheme, taking standard industrial classification (SIC) codes from CRSP and converting them according to the table that Kenneth French provides on his Internet site. ${ }^{8}$ The Fama-French 49-industry classification scheme provides balance with regard to the number of industries, the number of firms within each industry, and the homogeneity of intra-industry economic activity, all of which are important concerns when controlling for industry-related determinants of market reactions to $M \& A$ announcements.

For the tests of statistical significance, all reported $p$-values come from a bootstrap procedure. We use a percentile- $t$ approach, based on case-by-case resampling (Efron and Tibshirani, 1993). From the original data matrix, we draw, with replacement, 1,000 bootstrap samples with the same number of observations as in the original sample. For each bootstrap sample, a regression with White-adjusted standard errors provides heteroskedastic robust Student $t$-statistics (White, 1980). The $t$-statistics obtained from the original data then can be compared to the distribution of the bootstrap $t$-statistics to produce bootstrap $p$ values robust to heteroskedasticity. We report results using clustered standard errors as well (Petersen, 2009; Thompson, forthcoming) as a robustness check.

\footnotetext{
${ }^{8}$ See http://mba.tuck.dartmouth.edu/pages/faculty/ken.french/data_library.html.
} 


\section{Results}

\subsection{Main results}

Table 2 reports the estimation results of Equation (2), using the abnormal return premium as the dependent variable and with our control variables (see Appendix A for variable definitions). The coefficient of $S C A R_{d-1}$, the measure of investor reactions to the previous deal announcement, is positive and significant: The more positively (negatively) investors welcome the previous deal announcement, the higher (lower) the bid premium of the current deal. Thus CEOs appear receptive to signals sent by investors and adapt their behavior accordingly. This first result is consistent with learning and confirms the results reported by Luo (2005) about the probability of deal completion. Regarding the control variables and consistent with existing literature, the bid premium relates negatively to the target's size (see, e.g., Officer, 2003; Gaspar et al., 2005; Betton et al., 2009; Eckbo, 2009). Moreover, acquirers with higher institutional ownership concentrations pay lower premiums, and targets with higher Tobin's $q$ receive higher premiums (the latter variable is only marginally significant). These results do not control for the CEO effect, as highlighted in Section 2.4.

In Table 3, we present the estimation of the dynamic model defined in Equation (4), for which the dependent variable is the abnormal return premium. Column (1) reports results without control variables; column (2) includes the control variables. To quantify the severity of multicollinearity, we also report in column (2) the variance inflation factor of each variable from the right-hand side. Multicollinearity is possible for the dynamic model: If the explanatory variables correlate with the bid premium in the current deal and the control variables remain stable from deal to deal, the bid premium in the previous deal might be severely correlated with the other control variables. ${ }^{9}$ The stability of the coefficient estimates between columns (1) and (2) and the values of the variance inflation factor mitigate this concern though. ${ }^{10}$

\footnotetext{
${ }^{9}$ We thank an anonymous referee for pointing out this potential issue.

${ }^{10} \mathrm{~A}$ common rule of thumb is that if the variance inflation factor is greater than 5, multicollinearity is high; other authors propose 10 as a cut-off point (see Kutner et al., 2004).
} 
The main results thus are as follows: The dynamic model controls for the CEO effect and confirms that CEOs take into account signals sent by investors. Consistent with the learning hypothesis, the marginal effect of $S C A R_{d-1}$ on the bid premium is positive and significant; its effect also is economically substantial. A decrease of one standard deviation in abnormal returns in the previous deal leads the CEO to reduce the bid premium for the current deal by approximately $4.27 \%,{ }^{11}$ a percentage change of $-12 \%$ with respect to the previous deal by that CEO.

The coefficient of the autoregressive term, Premium $_{d-1}$, is positive, highly significant, and considerably less than 1 , which suggests that CEO bidding is persistent but not explosive. That is, CEOs who bid high continue to do so, and CEOs who bid low continue to bid low, though this persistence is only moderate. It is also worth noting that the $\mathrm{R}^{2}$ of the autoregressive model is $26.81 \%$, almost double that of the model in Table 2. Adding autoregressive terms to the bid premium regression thus greatly improves the explanatory power of the model.

Column (2) of Table 3 includes the interaction term between the CEO's previous bid premium and its associated market signal $\left(\right.$ Premium $\left._{d-1} \times S C A R_{d-1}\right)$. The coefficient is positive and highly significant ( $p$ value $=0.00$ ), which suggests that persistence in CEO bidding increases after positive market signals and decreases in response to negative ones. The coefficient of the $S C A R_{d-1}$ variable is negative but not significant at a conventional level. Our dynamic model thus reveals that signals sent by investors act more on the persistence of the CEO's bidding behavior from deal to deal than on the level of the bid premium in itself.

With respect to the control variables and in comparison with Table 2, target size and acquirer institutional ownership retain their sign and level of significance in Table 3, and the negative coefficient of the toehold variable becomes marginally significant with a $p$-value of 0.09 , consistent with Betton et al. (2009). The other control variables are either not significant or do not retain their significance across the

\footnotetext{
${ }^{11}$ This number is obtained by plugging the estimated coefficients in column (2) from Table 3 and the average premium of the previous deal (36.53\% for the sample of 194 deals) into the partial derivative of the current deal premium with respect to the previous deal SCAR: PPremium $_{t} / \partial S C A R_{t-1}=0.169 \times$ Premium $_{t-1}-0.019=0.169 \times 36.53 \%-0.019=4.27 \%$.
} 
two specifications. These differences with respect to the results reported in prior literature suggest that the autoregressive model implicitly controls for some determinants of the bid premium.

The results also support the empirical predictions of the learning hypothesis: The marginal effect of SCAR is positive and significant, which indicates that CEOs who receive positive signals increase their bidding, and those who receive negative signals decrease their bidding. Moreover, persistence in bidding increases following positive investor reactions and decreases following negative feedback. Explanations based on growing hubris receive no support from our results though, because persistence in bidding is substantially lower than 1 , regardless of the specification.

We turn to an investigation of the relationship among CEO past experience, hubris, and learning.

\subsection{Learning and CEO experience}

An observation in our sample refers to two successive deals completed by the same CEO-firm within a certain time period. Learning is captured by a significant relation between investor signals sent after the previous deal and CEO bidding behavior during the current deal. We might suspect that the total number of deals already undertaken by the CEO affect this relation; therefore, we carefully define learning as the process by which past experience transforms into knowledge, which should be cumulative over time.

We proxy for CEO past experience by computing the number of acquisitions by each CEO in the previous 24 months, prior to the announcement date of the previous deal. We take into account all acquisitions (public and private targets, as well as U.S. and non-U.S. targets) with deal sizes of greater than $\$ 1$ million and equal to at least 1\% of the acquirer's market value (see Masulis et al., 2007). We label our proxy Past Number of Deals.

The results in Table 4 include, in column (1), Past Number of Deals as such, without other variables of interests included in the regression specification. In column (2), we include the interaction between Past Number Deals and Premium $d_{-1} \times S C A R_{d-1}$ to study the effect of experience on the persistence of the CEO bidding behavior. As we showed in Section 4.1, investor reactions $\left(S C A R_{d-1}\right)$ mainly affect the persistence of CEO bidding behavior. Here we find that the coefficient of Past Number of Deals is 
negative in column (1) but not significant at conventional levels ( $p$-value $=0.14$ ). In column (2), the coefficient of the new interaction variable is positive and significant: CEO experience increases the sensitivity of the CEO's bidding behavior persistence to investor reactions. This finding is consistent with the learning hypothesis, because as the CEO accumulates more experience and transforms this greater experience into more knowledge, he or she pays more attention to investor signals. The marginal effect of SCAR remains positive and significant.

\subsection{Hubristic CEO bidding behavior}

To investigate the relation between hubris and learning, we use two proxies of CEO hubris. The first is the sign of the $S C A R_{d-1}$ variable. According to Roll (1986), hubristic CEOs overbid and destroy value (see also Malmendier and Tate, 2008), so hubris should be associated with a negative SCAR from the previous deal announcement. However, this proxy may be confusing, because it relies on the same variable as used to capture the signals sent by investors. Therefore, we also include a second hubris proxy based on the CEO's legal insider trading activities, which offers the benefit of being more exogenous. We track legal insider trading activity prior to a disappointing earnings announcement by each CEO. A CEO experiences hubris if (1) the firm's earnings announcement prior to the current M\&A deal generated a negative abnormal return (i.e., investors are disappointed by earnings announcement) and (2) over the two-year period before this earnings announcement, the CEO strictly increased net purchases. Our hubris proxy thus is a dummy variable that takes a value of 1 if both conditions are satisfied, and 0 otherwise. Appendix B explains this second proxy of hubris in more detail.

In Panel A of Table 5, we present the results using the sign of the first deal's SCAR as a proxy for hubris. In column (1), we interact the variable measuring investor reactions to the previous deal $\left(S C A R_{d-1}\right)$ with dummy variables for the sign of these investor reactions. The first interaction variable thus captures the effect of negative SCAR for the previous deal on CEO bidding behavior in the current deal; the second one notes the effect of positive SCAR for the previous deal. The coefficients associated 
with both variables are positive (the expected sign according to the learning hypothesis) but not significant.

In column (2), we adopt the autoregressive model and introduce the interaction of two dummy variables that identify the sign of the previous deal $S C A R$ with Premium $_{d-1} \times S C A R_{d-1}$ to capture the effect of negative and positive SCAR for the previous deal on the persistence of the CEO bidding behavior. The coefficients of these variables are positive and significant, consistent with the results in Table 3. That is, previous deal SCAR acts on CEO bidding behavior by modifying the persistence of CEO behavior. The positive coefficients are consistent with learning; after a negative (positive) investor reaction to the previous deal announcement, the CEO's bidding behavior becomes less (more) persistent. To the extent that the sign of SCAR for the previous deal correlates with CEO hubris, this result indicates that hubristic CEOs learn.

With Panel B of Table 5, we report the results using the hubris proxy based on the CEO's insider trading activities. In column (1), we regress the bid premium on the hubris proxy dummy variable, using the same set of control variables as in Table 2. The coefficient of the hubris dummy is negative and significant, consistent again with learning by hubristic CEOs. Because this hubris proxy is based on abnormal insider purchases before disappointing earnings announcements, the hubristic CEOs in our sample received a negative signal from investors before undertaking their current deal $(d$ in our sequence of two successive deals), which prompted them to adopt more cautious bidding behavior. The effect is highly significant. In column (2), the autoregressive model interacts the hubris dummy with Premium $_{d-1} \times S C A R_{d-1}$ to assess whether the change in persistence following investor reactions differs between hubristic and rational CEOs. The coefficient is not significant, and therefore, the impact of investor reactions to a previous deal on the persistence of the CEO bidding behavior is not significantly different for hubristic versus rational CEOs. The positive and significant marginal effect of SCAR confirms that both rational and hubristic CEOs learn, on average. 


\subsection{Robustness checks}

With the results in Table 6, we check whether the results from Table 3 are robust to alternative bid premium measures or are influenced by endogenous sample selection, as well as whether the reported $p$-values are biased by the presence of multiple sequences by the same CEOs, and if the estimates are sensitive to the time frame that spans the successive deals by this same CEO.

Alternative bid premium definitions. We investigate first whether the results are sensitive to the measure of the bid premium. Panel A of Table 6 examines two alternative definitions of the bid premium: the final offer premium (Officer, 2003) and the four-week premium reported in the Thomson-Reuters SDC database. Regardless of the premium definition, we obtain qualitatively the same results as in Table 3 . The previous deal premium has a positive and significant effect on the current deal premium, market signals significantly affect the bid premium through the persistence coefficient, and the marginal effect of market signals on the bid premium is positive and statistically significant ( $p$-value between 0.04 and 0.09 ).

Endogenous sample selection. Because our sample is restricted to completed M\&A transactions, public U.S. targets, and significant deals (greater than $\$ 1$ million, equal to at least $1 \%$ of acquirer's market value), generalizing our empirical evidence to a wider CEO population creates an endogenous sample selection issue. In particular, completed deals involve only auction winners, who may be more talented or more hubristic than CEOs who fail to complete an acquisition (Roll, 1986). For our study, this possibility becomes exacerbated by the focus on CEOs who make two successive, significant acquisitions during a relatively short time. Following Li and Prabhala (2007), we therefore adopt Heckman's (1979) two-stage procedure to account for sample selection endogeneity. The first stage uses a probit model to determine the probability that a CEO will undertake an acquisition in a given year. The second-stage regression then employs an inverse Mills ratio (or Heckman's Lambda) and adjusts the standard errors according to the procedure described by Greene (2008, pp. 886-887).

The first-stage probit uses CEOs identified in the ExecuComp database for the period 1992-2007 and the sample of M\&As described in Section 3.2. The dependent variable equals 1 when a CEO completes a deal in a given year. The independent variables include size (acquirer firms are larger than target firms), 
the leverage and liquidity ratios (financially constrained firms are less likely to undertake acquisitions), the market-to-book ratio (Shleifer and Vishny, 2003), the liquidity index (which captures the intensity of intercorporate transactions at the industry level and correlates with M\&A waves; Schlingemann et al., 2002), and the number of deals completed by the CEO in the previous 24 months (e.g., Schipper and Thompson, 1983; Malatesta and Thompson, 1985; Fuller et al., 2002). ${ }^{12}$ This stage provides the information required to compute Heckman's Lambda. In the second stage, we include Heckman's Lambda to control for sample selection. In the interest of brevity, we do not report the first-stage probit results here. ${ }^{13}$

Panel B of Table 6 replicates Table 3 with Heckman's Lambda as an additional control variable. The dependent variable is the abnormal return premium. The coefficient of the previous deal premium variable remains positive and statistically significant, and the point estimates are close to those reported in Table 3, which used ordinary least squares. The same conclusions hold for the interaction variable and the marginal effect of SCAR on the bid premium, which confirms the role of learning in CEO bidding. Introducing Heckman's Lambda does not significantly affect the conclusions regarding the control variables. Finally, sample selection does not appear to be an issue, because Heckman's Lambda is never significant. We must remain cautious though when generalizing our results to the wide CEO population; the two-stage approach controls for the probability that a given CEO will complete a deal in a given year but not the probability of two successive, significant deals on U.S. targets. These additional requirements may be sources of additional biases.

CEO effect. Some CEOs undertake several sequences of two successive deals (e.g., 164 CEOs undertake 315 sequences of two acquisitions within 12 months). Conceivably, these observations might not be independent. To control for correlations between firms and time periods, we also report in Panel C

\footnotetext{
${ }^{12}$ Size is the natural logarithm of the firm market value. Leverage is the ratio of long-term and current liabilities to total assets. The liquidity ratio is the ratio of cash to total assets. The market-to-book ratio is the ratio of the market value of equity to the book value of equity. The liquidity index is the value of corporate control transactions during a year, relative to the aggregate book value of assets of firms in each Fama-French industry.

${ }^{13}$ The first-stage probit results are available on request.
} 
of Table 6 the results we obtained using clustered standard errors with firm and year dummies (Petersen, 2009; Thompson, forthcoming). The dependent variable is the abnormal return premium. The results confirm the significant and positive coefficients of the previous deal premium variable. The marginal effect of $S C A R$ is also significantly positive, with a $p$-value of 0.07 .

Time frame. Thus far, an observation has been defined as two successive acquisitions by a CEO in 12 months. Panel D of Table 6 investigates whether the results hold also for time frames of 6 and 24 months. The dependent variable is the abnormal return premium.

The time frame matters. Specifically, though previous deal premium is still positive and significant, as is the coefficient of the interaction between $S C A R$ and the premium from the previous deal, the SCAR coefficient becomes negative and significant for both the 6- and 24-month time frames. Moreover, the marginal effect of SCAR loses its significance. These results suggest that learning has a weaker effect as the time frame contracts or expands between successive deals. As Hayward (2002) emphasizes, acquisitions that are temporally too close or too distant appear to hamper organizational learning.

\section{Summary and conclusion}

Recent academic studies indicate that acquirers' CARs decline from deal to deal in M\&A programs. How can we interpret such empirical evidence? Is it an unambiguous empirical evidence of hubristic CEOs behaviors? The question is important. Toward the end of the 1990s, at the crest of the M\&A wave, the aggregate deal value of year 2000 acquisitions initiated by U.S. bidders reached $\$ 1.1$ trillion. With a total market capitalization (NYSE, AMEX, and NASDAQ) of approximately $\$ 15.5$ trillion at the end of the same year, acquisitions amounted to roughly $7 \%$ of total market capitalization.

Using the concept of CEO learning through the acquisition sequence, ADR (2009) provide an alternative explanation of the declining trend of CARs from deal to deal. We test the main implications of the learning hypothesis by studying CEO bidding behavior in sequences of two successive deals and determining whether CEO behavior is affected by investor reactions to the first deal in the sequence. 
Our main empirical evidence derives from a sample of successive deals with public U.S. targets of significant size, conducted by the same CEO-firm couples during 12 months in 1992-2007. We estimate a dynamic model of CEO bidding by conditioning the bid premium in the current deal on (1) the bid premium in the previous deal, (2) the investor reaction to the previous deal, and (3) the interaction between these two variables. Our results are consistent with CEO learning from investor reactions. The results also reveal the persistence of CEO bidding behavior: CEOs who bid high continue to bid high, whereas those who bid low continue to bid low. Persistence is a source of heterogeneity in CEO bidding that previous literature has ignored. We finally explore the interaction between learning and the CEO's experience and hubris. Our results confirm that experience significantly improves learning and that both rational and hubristic CEOs learn. This empirical evidence seems robust to endogenous sample selection, but taking into account the composition of our sample of M\&A transactions, we remain cautious about the generalization of our findings to the CEO population as a whole. 


\section{Appendix A: Variable definitions}

(Compustat is the source of variables referred to by item number)

\begin{tabular}{|c|c|}
\hline Variable & Description \\
\hline \multicolumn{2}{|c|}{ Dependent Variable } \\
\hline $\begin{array}{l}\text { Abnormal Return } \\
\text { Premium }\end{array}$ & $\begin{array}{l}\text { The sum of the target daily abnormal returns (AR) from day }-42 \text { to the delisting date or } \\
\text { to day } 126 \text { relative to the announcement date. Daily ARs are from the Beta-one model, } \\
\text { which subtracts the daily market portfolio return from the daily return of each } \\
\text { company. The selected market portfolio is the value-weighted CRSP index. }\end{array}$ \\
\hline $\begin{array}{l}\text { Final Offer } \\
\text { Premium }\end{array}$ & $\begin{array}{l}\text { The final offer premium (in percentage) corresponds to the final price offered per stock } \\
\text { (field HOSTPR in Thomson-Reuters SDC database) deflated by the target stock price } \\
42 \text { days before the announcement date }\end{array}$ \\
\hline $\begin{array}{l}\text { Four-Week } \\
\text { Premium }\end{array}$ & $\begin{array}{l}\text { The premium (in percentage) of the offer price to the target closing stock price four } \\
\text { weeks prior to the original announcement date (field PREM4WK in Thomson-Reuters } \\
\text { SDC database). }\end{array}$ \\
\hline \multicolumn{2}{|l|}{ Market Signals } \\
\hline SCAR & $\begin{array}{l}\text { The acquirer's standardized CARs from day }-5 \text { to day }+5 \text {, relative to the announcement } \\
\text { date of the previous deal. Daily abnormal returns are computed following the same } \\
\text { method as for the abnormal return premium. The standard deviation used to } \\
\text { standardize the CAR is computed from daily abnormal returns from day }-242 \text { to day - } \\
43 \text {, relative to the announcement date }\end{array}$ \\
\hline \multicolumn{2}{|c|}{ Other Key Variables } \\
\hline $\begin{array}{l}\text { Past Number of } \\
\text { Deals }\end{array}$ & $\begin{array}{l}\text { The number of acquisitions by the CEO in the } 24 \text { months before the announcement } \\
\text { date of the previous deal. To construct this variable, we considered a sample of M\&A } \\
\text { deals that included public, private, U.S., and non-U.S. targets with a deal size above } \$ 1 \\
\text { million and equal to at least } 1 \% \text { of the acquirer's market value. }\end{array}$ \\
\hline $\begin{array}{l}\text { Dummy Negative } \\
\text { SCAR }\end{array}$ & Dummy variable: 1 when the previous deal SCAR is negative, and 0 otherwise. \\
\hline $\begin{array}{l}\text { Dummy Positive } \\
\text { SCAR }\end{array}$ & Dummy variable: 1 when the previous deal SCAR is positive, and 0 otherwise. \\
\hline Hubris & $\begin{array}{l}\text { Dummy variable: } 1 \text { for hubristic CEO, } 0 \text { otherwise. The CEO experiences hubris if (1) } \\
\text { the firm's earnings announcement prior to the current M\&A deal generated a negative } \\
\text { abnormal return and (2) over the two-year period before this earnings announcement, } \\
\text { the CEO strictly increased net purchases. (See Appendix B for more detail.) }\end{array}$ \\
\hline \multicolumn{2}{|l|}{ Control Variables } \\
\hline Stock & Dummy variable: 1 for purely stock-financed deals, and 0 otherwise. \\
\hline Target Size & $\begin{array}{l}\text { Natural logarithm of the market value of equity (number of shares outstanding } \\
\text { multiplied by the stock price) at day }-42 \text { relative to the announcement date. }\end{array}$ \\
\hline Tobin's $q$ Ratio & $\begin{array}{l}\text { Market value of assets over book value of assets: (item6 - item } 60+\text { item } 25 \times \\
\text { item199)/item6. }\end{array}$ \\
\hline Toehold & Percentage of target stock held by the acquirer prior to the announcement date. \\
\hline Related Deal & $\begin{array}{l}\text { Dummy variable: } 1 \text { for deal in which both the bidder and the target are in the same } \\
\text { Fama-French industry. The Fama-French industry is obtained after extracting SIC } \\
\text { codes from the CRSP database and converting them using the table provided by } \\
\text { Kenneth French on his Web site. }{ }^{14}\end{array}$ \\
\hline
\end{tabular}

\footnotetext{
${ }^{14}$ http://mba.tuck.dartmouth.edu/pages/faculty/ken.french/data_library.html.
} 


\begin{tabular}{|l|l|}
\hline GIM Index & $\begin{array}{l}\text { Proxy for acquirer's corporate governance quality, based on Gompers et al.'s (2003) } \\
\text { index, constructed using information from the Investor Responsibility Research Center } \\
\text { (IRRC) database. Higher index levels correspond to more managerial power. }\end{array}$ \\
\hline $\begin{array}{l}\text { Institutional } \\
\text { Ownership }\end{array}$ & $\begin{array}{l}\text { Percentage of target firm's equity owned by institutional investors, as in Gaspar et al. } \\
\text { (2005), using SDA/Spectrum as database. The variable is lagged by two quarters with } \\
\text { respect to the deal announcement quarter. }\end{array}$ \\
\hline $\begin{array}{l}\text { Institutional } \\
\text { Concentration }\end{array}$ & $\begin{array}{l}\text { Herfindahl index of the institutional investors shareholdings in the target, as in Gaspar } \\
\text { et al. (2005), using SDA/Spectrum as data source. The variable is lagged by two } \\
\text { quarters with respect to deal announcement quarter. }\end{array}$ \\
\hline
\end{tabular}

\section{Appendix B: Hubris proxy based on CEO's legal insider trading}

A given CEO experiences hubris if two conditions are fulfilled: (1) the firm's earnings announcement prior to the current M\&A deal of a CEO generates a negative abnormal return (i.e., investors are disappointed by the earnings announcement) and (2) in the two-year period before this earnings announcement, the CEO strictly increases his or her net purchases. Our hubris proxy is therefore a dummy variable that takes a value of 1 if both of these two conditions are satisfied, and 0 otherwise. Using insider trading variation offers a control for known insider trading activity patterns. Insiders in particular are net sellers on average, perhaps for diversification reasons (see Lakonishok and Lee, 2001). Moreover, insider trading exhibits seasonality, perhaps due to restrictions imposed by the company (Bettis et al., 2000). We use the following procedure: We first identify the earnings announcement just before the CEO's current M\&A deal. We then compute the abnormal returns associated with this earnings announcement over a 11day event window (using the market model as the normal return-generating process). A disappointing earnings announcement is indicated by a negative abnormal return. Before analyzing the CEO insider trading activities, we skip the three-month period before the identified earnings announcement. Our goal is to ensure that the CEO's insider trading activity is based on anticipation of future firm prospects and not contaminated by privileged information with respect to the forthcoming earnings announcement. We finally aggregate the CEO's net purchases over two successive previous 12-month periods and compute their difference.

We obtain CEO insider transactions from Thomson Financial; its Insider Filing Database captures all insider activities on Securities and Exchange Commission forms 3, 4, and 5. Following prior studies, we 
focus on open market purchases and sales, as reported in Table 1 of Form 4 (see, e.g., Lakonishok and Lee, 2001; Ke et al., 2003; Aktas et al., 2008). We discard transactions following option exercises. To guarantee data quality, we remove all insider trading records assigned codes " $\mathrm{A}$ " or "S" by Thomson Financial. ${ }^{15} \mathrm{We}$ collect earnings announcements from Thomson ONE Banker database.

\footnotetext{
${ }^{15}$ Thomson Financial estimates the accuracy of insider transactions by checking external sources. Code "S" indicates no cleansing attempted, and the security does not meet Thomson Financial's collection requirements; code "A" indicates that numerous data elements are missing or invalid and that reasonable assumptions cannot be made.
} 


\section{References}

Ahern, K.R., 2008. The returns to repeat acquirers. Unpublished working paper, University of Michigan.

Aktas, N., de Bodt, E., Roll, R., 2009. Learning, hubris, and corporate serial acquisitions. Journal of Corporate Finance 15, 543-561.

Aktas, N., de Bodt, E., Van Oppens, H., 2008. Legal insider trading and market efficiency. Journal of Banking and Finance 32, 1379-1392.

Bates, T.H., Lemmon, M.L., 2003. Breaking up is hard to do? An analysis of termination fee provisions and merger outcomes. Journal of Financial Economics 69, 460-504.

Bertrand, M., Schoar, A., 2003. Managing with style: the effect of managers on firm policies. Quarterly Journal of Economics 118, 1169-1208.

Bettis, C.J., Coles, J.L., Lemmon, M.L., 2000. Corporate policies restricting trading by insiders. Journal of Financial Economics 57, 191-220.

Betton, S., Eckbo, B.E., 2000. Toeholds, bid jumps and expected payoffs in takeovers. Review of Financial Studies 13, 841-882.

Betton, S., Eckbo, B.E., Thorburn, K.S., 2008. Corporate takeovers. In: Eckbo, B.E. (Ed.), Handbook of Corporate Finance, Empirical Corporate Finance. Elsevier, North-Holland, Vol. 2, 291-429.

Betton, S., Eckbo, B.E., Thorburn, K.S., 2009. Merger negotiations and the toehold puzzle. Journal of Financial Economics 91, 158-178.

Billett, M.T., Qian, Y., 2008. Are overconfident managers born or made? Evidence of self-attribution bias from frequent acquirers. Management Science 54, 1037-1051.

Boone, A.L., Mulherin, H.L., 2007. How are firms sold? Journal of Finance 62, 847-875.

Bulow, J.I., Huang, M., Klemperer, H.J., 1999. Toeholds and takeovers. Journal of Political Economy 107, 427-454.

Burkart, M., 1995. Initial shareholdings and overbidding in takeover contests. Journal of Finance, 50, 1491-1515.

Chang, C., Dasgupta, S., Hilary, G., forthcoming. CEO ability, pay and firm performance. Management Science.

Chen, Q., Goldstein, I., Jiang, W., 2007. Price informativeness and investment sensitivity to stock price. Review of Financial Studies 20, 619-650.

Conn, R.L., Cosh, A., Guest, P.M., Hugues, A., 2004. Why must all good things come to an end? The performance of multiple acquirers. In Academy of Management (eds.) Creating Actionable Knowledge: Academy of Management Best Paper Proceedings (64th), 6-11.

Croci, E., 2005. Why do managers make serial acquisitions? An investigation of performance predictability in serial acquisitions. Unpublished working paper, SSRN Abstract Id: 727503.

Dasgupta, S., Tsui, K., 2004. Auction with cross-shareholdings. Economic Theory, 24, 163-194.

Datta, S., Iskandar-Datta, M., Raman, K., 2001. Executive compensation and corporate acquisition decisions. Journal of Finance 56, 2299-2336.

DeMarzo, P.M., Kremer, I., Skrzypacz, A., 2005. Bidding with securities: Auctions and security design. American Economic Review 95, 936-959.

Dow, J., Gorton, G., 1997. Stock market efficiency and economic efficiency: Is there a connection? Journal of Finance 52, 1087-1129. 
Eckbo, B.E., 2009, Bidding strategies and takeover premiums: A review. Journal of Corporate Finance 15, $149-178$.

Eckbo, B.E., Giammarino, R.M., Heinkel, R.L., 1990. Asymmetric information and the medium of exchange in takeovers: Theory and tests. Review of Financial Studies 3, 651-675.

Efron, B., Tibshirani, R.J., 1993. An Introduction to the Bootstrap. Chapman \& Hall, London.

Fishman, M.J., 1988. A theory of preemptive takeover bidding. RAND Journal of Economics 19, 88-101.

Fishman, M.J., 1989. Pre-emptive bidding and the role of the medium of exchange in acquisitions. Journal of Finance 44, 41-57.

Fuller, K., Netter, J., Stegemoller, M., 2002. What do returns to acquiring firms tell us? Evidence from firms that make many acquisitions. Journal of Finance 57, 1763-1793.

Gaspar, J., Massa, M., Matos, P., 2005. Shareholder investment horizons and the market for corporate control. Journal of Financial Economics 76, 135-165.

Gompers, P.A., Ishii, J.L., Metrick, A., 2003. Corporate governance and equity prices. Quarterly Journal of Economics 118, 107-155.

Greene, W.H., 2008. Econometric Analysis. Pearson Prentice Hall, Englewood Cliffs, NJ.

Hansen, R.G., 1987. A theory for the choice of exchange medium in mergers and acquisitions. Journal of Business 60, 75-95.

Hansen, R.G., 2001. Auctions of companies. Economic Inquiry 39, 30-43.

Hartzell, J.C., Ofek, E., Yermack, D., 2004. What's in it for me? CEOs whose firms are acquired. Review of Financial Studies 17, 37-61.

Hayward, M., 2002. When do firms learn from their acquisition experience? Evidence from 1990-1995. Strategic Management Journal 23, 21-39.

Heckman, J.J., 1979. Sample selection bias as a specification error. Econometrica 47, 153-161.

Ismail, A., 2008. Which acquirers gain more, single or multiple? Recent evidence from the USA market. Global Finance Journal 19, 72-84.

Kau, J.B., Linck, J.S., Rubin, P.H., 2008. Do managers listen to the market? Journal of Corporate Finance $14,347-362$.

Ke, B., Huddart, S.J., Petroni, K.R., 2003. What insiders know about future earnings and how they use it: Evidence from insider trades. Journal of Accounting and Economics 35, 315-346.

Klasa, S., Stegemoller, M., 2007. Takeover activity as a response to time-varying changes in investment opportunity sets: Evidence from takeover sequences. Financial Management 36, 19-43.

Kolb, D., 1984. Experiential Learning: Experience as the Source of Learning and Development. PrenticeHall, Inc., Englewood Cliffs, N.J.

Kutner, M., Nachtsheim, C., Neter, J., 2004. Applied Linear Regression Models. McGraw-Hill/Irwin, $4^{\text {th }}$ Edition.

Lakonishok, J., Lee, I., 2001. Are insider trades informative? Review of Financial Studies, 14, 79-111.

Li, K., Prabhala, N.R., 2007. Self-selection models in corporate finance. In: Eckbo, B.E. (Ed.), Handbook of Corporate Finance, Empirical Corporate Finance. Elsevier, North-Holland Vol. 1, 37-83.

Luo, Y., 2005. Do insiders learn from outsiders? Evidence from mergers and acquisitions. Journal of Finance 60, 1951-1982. 
Malatesta, P.H., Thompson, R., 1985. Partially anticipated events: A model of stock price reactions with an application to corporate acquisitions. Journal of Financial Economics 14, 237-250.

Malmendier, U., Tate. G.A., 2008. Who makes acquisitions? CEO overconfidence and the market's reaction. Journal of Financial Economics 89, 20-43.

Masulis, R.W., Wang, C., Xie, F., 2007. Corporate governance and acquirer returns. Journal of Finance $62,1851-1888$.

Moeller, T., 2005. Let's make a deal! How shareholders control impacts merger payoff. Journal of Financial Economics 76, 167-190.

Netter, J., Stegemoller, M., Wintoki, M.B., 2010. A study of over 250,000 (or less) mergers and acquisitions from 1992-2009. Unpublished working paper, SSRN Abstract Id:1510724.

Officer, M., 2003. Termination fees in mergers and acquisitions. Journal of Financial Economics 69, 431437.

Petersen, M.A., 2009. Estimating standard errors in finance panel data sets: Comparing approaches. Review of Financial Studies 22, 435-480.

Rhodes-Kropf, M., Viswanathan, S., 2004. Market valuation and merger waves. Journal of Finance 59, 2685-2718.

Roll, R., 1986. The hubris hypothesis of corporate takeovers. Journal of Business 59, 197-216.

Schipper, K., Thompson, R., 1983. Evidence on the capitalized value of merger activity for acquiring firms. Journal of Financial Economics 11, 85-119.

Schlingemann, F.P., Stulz, R.M., Walkling, R.A., 2002. Divestitures and the liquidity of the market for corporate assets. Journal of Financial Economics 64, 117-144.

Schwert, W.G., 1996. Markup pricing in mergers and acquisitions. Journal of Financial Economics 41, 153-192.

Shleifer, A., Vishny, R.W., 2003. Stock market driven acquisitions. Journal of Financial Economics 70, 295-311.

Subrahmanyam, A., Titman, S., 1999. The going-public decision and the development of financial markets. Journal of Finance 54, 1045-1082.

Thompson, S.B., forthcoming. Simple formulas for standard errors that cluster by both firm and time. Journal of Financial Economics.

White, H., 1980. A heteroskedasticity-consistent covariance matrix estimator and a direct test for heteroskedasticity. Econometrica 48, 817-838. 
Table 1

Summary statistics

This table reports sample period means and medians for the three bid premium definitions and the acquirer's cumulative abnormal returns (CAR). The indices $d$ and $d-1$ denote, respectively, the current and previous deal by a given CEO in a sequence of two deals undertaken within 12 months. The final column displays the $p$-value from a difference of means test. $N$ and \%Negative denote the number of observations and the proportion of negative values in the sample for the corresponding variable, respectively. SCAR stands for standardized CAR. Variable definitions are in Appendix A.

\begin{tabular}{|c|c|c|c|}
\hline & Deal $d$ & Deal $d-1$ & $p$-value \\
\hline \multicolumn{4}{|c|}{ Panel A. Abnormal Return Premium $(N=315)$} \\
\hline $\mathrm{N}$ & 315 & 315 & \multirow{4}{*}{0.68} \\
\hline Mean & $32.33 \%$ & $34.13 \%$ & \\
\hline Median & $28.11 \%$ & $29.62 \%$ & \\
\hline$\%$ Negative & $12.06 \%$ & $13.33 \%$ & \\
\hline \multicolumn{4}{|c|}{ Panel B. Final Offer Premium $(N=296)$} \\
\hline Mean & $45.02 \%$ & $46.20 \%$ & \multirow[t]{3}{*}{0.83} \\
\hline Median & $39.46 \%$ & $39.10 \%$ & \\
\hline$\%$ Negative & $6.42 \%$ & $5.74 \%$ & \\
\hline \multicolumn{4}{|c|}{ Panel C. Four-Week Premium $(N=284)$} \\
\hline Mean & $40.82 \%$ & $43.20 \%$ & \multirow[t]{3}{*}{0.54} \\
\hline Median & $35.33 \%$ & $35.93 \%$ & \\
\hline$\%$ Negative & $3.87 \%$ & $2.82 \%$ & \\
\hline \multicolumn{4}{|c|}{ Panel D. Acquirer CAR $(N=381)$} \\
\hline Mean CAR & $-1.10 \%$ & $-0.12 \%$ & \multirow[t]{3}{*}{0.24} \\
\hline Median CAR & $-1.31 \%$ & $-0.78 \%$ & \\
\hline$\%$ Negative CAR & $58.53 \%$ & $54.86 \%$ & \\
\hline Mean CAR St. dev. & $6.89 \%$ & $6.98 \%$ & \multirow{3}{*}{0.05} \\
\hline Mean SCAR & -0.239 & -0.125 & \\
\hline Median SCAR & -0.219 & -0.140 & \\
\hline
\end{tabular}


Table 2

Bidding behavior and market signals

The dependent variable is the abnormal return premium. An observation is a sequence of two successive deals undertaken by the same CEO-firm within 12 months. Coefficients are estimated by ordinary least squares. Variable definitions are in the Appendix A. $R^{2}$ and $F$-Statistic denote the R-square and the Fisher statistic for the regression, respectively. $P$-values are obtained using the bootstrap procedure described in Section 3.3.

\begin{tabular}{lcc}
\hline Independent variable & Coefficient & $p$-value \\
\hline Intercept & 0.647 & 0.00 \\
Variable of interest & & 0.05 \\
$\quad$ SCAR $_{d-1}$ & 0.040 & \\
Control variable & & 0.58 \\
$\quad$ Stock & 0.015 & 0.00 \\
Target Size & -0.047 & 0.20 \\
Acquirer Tobin's $q$ & 0.020 & 0.12 \\
Target Tobin's $q$ & 0.038 & 0.41 \\
Toehold & -0.061 & 0.62 \\
Related Deal & 0.015 & 0.20 \\
Acquirer GIM Index & -0.008 & 0.71 \\
Acquirer Inst. Ownership & 0.014 & 0.01 \\
$\quad$ Acquirer Inst. Concentration & -1.513 & \\
Number of observations & 208 & \\
Adjusted- $R^{2}$ & $15.70 \%$ & \\
$F$-Statistic & 3.67 & \\
\hline
\end{tabular}


Table 3

Bidding behavior persistence and market signals

The dependent variable is the abnormal return premium in all specifications. An observation is a sequence of two successive deals undertaken by the same CEO-firm within 12 months. Coefficients are estimated by ordinary least squares. Variable definitions are in Appendix A. $R^{2}$ and $F$-Statistic denote the R-square and the Fisher statistic for the regression, respectively. $P$-values are obtained using the bootstrap procedure described in Section 3.3. For specification (2), the marginal effect of $S C A R$ on the bid premium is also reported, which corresponds to the partial derivative estimated using the average bid premium of the previous deal. VIF stands for variance inflation factor.

\begin{tabular}{|c|c|c|c|c|c|}
\hline \multirow{2}{*}{ Independent variable } & \multicolumn{2}{|c|}{ (1) } & \multicolumn{3}{|c|}{ (2) } \\
\hline & Coef. & $p$-value & Coef. & $p$-value & VIF \\
\hline Intercept & 0.223 & 0.00 & 0.605 & 0.00 & \\
\hline $\begin{array}{l}\text { Variable of interest } \\
\text { Premium }_{d-1} \\
\text { SCAR }_{d-1} \\
\text { Premium }_{d-1} \times \operatorname{SCAR}_{d-1}\end{array}$ & $\begin{array}{c}0.279 \\
-0.008 \\
0.089\end{array}$ & $\begin{array}{l}0.00 \\
0.39 \\
0.04\end{array}$ & $\begin{array}{c}0.224 \\
-0.019 \\
0.169\end{array}$ & $\begin{array}{l}0.00 \\
0.16 \\
0.00\end{array}$ & $\begin{array}{l}1.160 \\
1.495 \\
1.516\end{array}$ \\
\hline $\begin{array}{l}\text { Control variable } \\
\text { Stock } \\
\text { Target Size } \\
\text { Acquirer Tobin's } q \\
\text { Target Tobin's } q \\
\text { Toehold } \\
\text { Related Deal } \\
\text { Acquirer GIM Index } \\
\text { Acquirer Inst. Ownership } \\
\text { Acquirer Inst. Concentration }\end{array}$ & & & $\begin{array}{c}0.010 \\
-0.048 \\
0.030 \\
0.019 \\
-0.145 \\
-0.004 \\
-0.010 \\
0.004 \\
-1.289\end{array}$ & $\begin{array}{l}0.66 \\
0.00 \\
0.09 \\
0.14 \\
0.09 \\
0.89 \\
0.13 \\
0.91 \\
0.02\end{array}$ & $\begin{array}{l}1.102 \\
1.073 \\
1.596 \\
1.605 \\
1.067 \\
1.060 \\
1.067 \\
1.147 \\
1.132\end{array}$ \\
\hline Marginal effect of SCAR & $2.20 \%$ & 0.09 & $4.27 \%$ & 0.04 & \\
\hline $\begin{array}{l}\text { Number of observations } \\
\text { Adjusted- } R^{2} \\
F \text {-Statistic }\end{array}$ & $\begin{array}{c}314 \\
10.10 \% \\
8.74\end{array}$ & & $\begin{array}{c}194 \\
26.81 \% \\
5.52\end{array}$ & & \\
\hline
\end{tabular}


Table 4

Learning and CEO experience

The dependent variable is the abnormal return bid premium. An observation is a sequence of two successive deals undertaken by the same CEO-firm within a 12-month time frame. Variable definitions are in Appendix A. Each regression includes the same set of control variables as in Table 2, whose estimates are not reported. $R^{2}$ and $F$ Statistic denote the R-square and the Fisher statistic for the regression, respectively. $P$-values are obtained using the bootstrap procedure described in Section 3.3. The marginal effect of SCAR on the bid premium is also reported, which corresponds to the partial derivative estimated using the average bid premium of the previous deal. Past Number of Deals corresponds to the number of acquisitions by the CEO during the 24 months prior to the announcement date of the first deal in a sequence of two successive deals.

\begin{tabular}{|c|c|c|c|c|}
\hline \multirow[b]{2}{*}{ Independent variable } & \multicolumn{2}{|c|}{ (1) } & \multicolumn{2}{|c|}{$(2)$} \\
\hline & Coef. & $p$-value & Coef. & $p$-value \\
\hline Intercept & 0.753 & 0.00 & 0.617 & 0.00 \\
\hline \multicolumn{5}{|l|}{ Variable of interest } \\
\hline Premium $_{d-1}$ & & & 0.197 & 0.00 \\
\hline $\operatorname{SCAR}_{d-1}$ & & & -0.019 & 0.17 \\
\hline $\operatorname{Premium}_{d-1} \times \mathrm{SCAR}_{d-1}$ & & & 0.079 & 0.12 \\
\hline Past Number of Deals & -0.006 & 0.14 & & \\
\hline Premium $_{d-1} \times \operatorname{SCAR}_{d-1} \times$ Past Number of Deals & & & 0.020 & 0.05 \\
\hline Control variable & Yes & & Yes & \\
\hline Marginal effect of SCAR & & & $4.12 \%$ & 0.05 \\
\hline Number of observations & 885 & & 194 & \\
\hline Adjusted- $R^{2}$ & $11.01 \%$ & & $27.72 \%$ & \\
\hline$F$-Statistic & 9.82 & & 4.90 & \\
\hline
\end{tabular}


Table 5

Hubristic CEO and learning

The dependent variable is the abnormal return bid premium. An observation is a sequence of two successive deals undertaken by the same CEO-firm within 12 months. Panel A features the sign of the previous deal SCAR to define hubristic CEOs, and Panel B reflects the hubris proxy based on the CEO's legal insider trading activities before disappointing earnings announcements. Variable definitions are in Appendices A and B. The coefficients are estimated using ordinary least squares. Each regression includes the same set of control variable as in Table 2, whose estimates are not reported. $R^{2}$ and F-Statistic denote the R-square and the Fisher statistic for the regression, respectively. $P$-values are obtained using the bootstrap procedure described in Section 3.3. The marginal effect of $S C A R$ on the bid premium is also reported, which corresponds to the partial derivative estimated using the average bid premium of the previous deal.

Panel A. Hubris proxy based on the sign of the first deal SCAR

\begin{tabular}{|c|c|c|c|c|}
\hline \multirow[b]{2}{*}{ Independent variable } & \multicolumn{2}{|c|}{ (1) } & \multicolumn{2}{|c|}{ (2) } \\
\hline & Coef. & $p$-value & Coef. & $p$-value \\
\hline Intercept & 0.628 & 0.00 & 0.623 & 0.00 \\
\hline 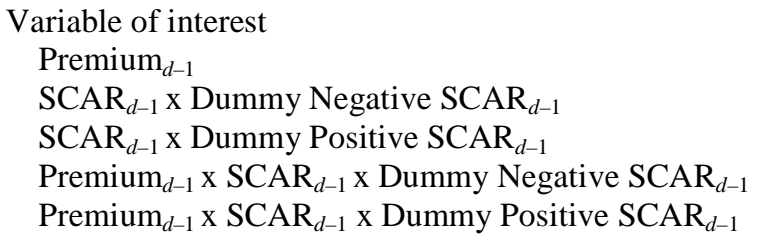 & $\begin{array}{l}0.019 \\
0.067\end{array}$ & $\begin{array}{l}0.36 \\
0.11\end{array}$ & $\begin{array}{c}0.208 \\
-0.011 \\
-0.024 \\
0.156 \\
0.192\end{array}$ & $\begin{array}{l}0.00 \\
0.52 \\
0.24 \\
0.00 \\
0.03\end{array}$ \\
\hline Control variable & Yes & & Yes & \\
\hline Marginal effect of SCAR & & & $3.62 \%$ & 0.08 \\
\hline $\begin{array}{l}\text { Number of observations } \\
\text { Adjusted- } R^{2} \\
F \text {-Statistic }\end{array}$ & $\begin{array}{c}208 \\
15.91 \% \\
3.07\end{array}$ & & $\begin{array}{c}194 \\
26.85 \% \\
4.35\end{array}$ & \\
\hline
\end{tabular}

Panel B. Hubris proxy based on insider trading activities before disappointing earnings announcements

\begin{tabular}{|c|c|c|c|c|}
\hline \multirow[b]{2}{*}{ Independent variable } & \multicolumn{2}{|c|}{ (1) } & \multicolumn{2}{|c|}{ (2) } \\
\hline & Coef. & $p$-value & Coef. & $p$-value \\
\hline Intercept & 0.742 & 0.00 & 0.608 & 0.00 \\
\hline Variable of interest & & & & \\
\hline Premium $_{d-1}$ & & & 0.222 & 0.00 \\
\hline $\operatorname{SCAR}_{d-1}$ & & & -0.018 & 0.19 \\
\hline $\operatorname{Premium}_{d-1}$ x SCAR $\operatorname{SA}_{d-1}$ & & & 0.171 & 0.00 \\
\hline Hubris & -0.056 & 0.02 & & \\
\hline Premium $_{d-1} \times \mathrm{SCAR}_{d-1} \times$ Hubris & & & -0.033 & 0.62 \\
\hline Control variable & Yes & & Yes & \\
\hline Marginal effect of SCAR & & & $4.40 \%$ & 0.04 \\
\hline Number of observations & 885 & & & 194 \\
\hline Adjusted- $R^{2}$ & $11.39 \%$ & & & $26.82 \%$ \\
\hline$F$-Statistic & 10.20 & & & 4.68 \\
\hline
\end{tabular}


Table 6

Robustness checks

This table presents various robustness checks. Panel A compares ordinary least square (OLS) for alternative bid premium definitions as the dependent variable. Panel B reports two-stage least square (TSLS) estimates for the abnormal return premium as the dependent variable. The first-stage probit is not reported. Heckman's Lambda is the inverse Mills ratio, obtained using the two-stage Heckman (1979) procedure described in Section 3.3. In Panel C, to account for the residual dependence created by the CEO-firm effect, $p$-values are computed using clustered standard errors. Panel D reports results using two alternative time frames: An observation is a sequence of two successive deals undertaken by the same CEO-firm within 6 or 24 months. The dependent variable is the abnormal return bid premium in Panels B, C, and D. Variable definitions are in Appendix A. Each regression includes the same set of control variables as in Table 2 whose estimates are not reported. $R^{2}$ and $F$-Statistic denote the R-square and the Fisher statistic for the regression, respectively. The marginal effect of $S C A R$ on the bid premium is also reported, which corresponds to the partial derivative estimated using the average bid premium of the previous deal.

Panel A. Alternative bid premium definitions

\begin{tabular}{|c|c|c|c|c|c|c|}
\hline \multirow[b]{2}{*}{ Independent variable } & \multicolumn{2}{|c|}{$\begin{array}{l}\text { Abnormal Return } \\
\text { Premium }\end{array}$} & \multicolumn{2}{|c|}{$\begin{array}{l}\text { Final Offer } \\
\text { Premium }\end{array}$} & \multicolumn{2}{|c|}{$\begin{array}{l}\text { Four-Week } \\
\text { Premium }\end{array}$} \\
\hline & Coef. & $p$-value & Coef. & $p$-value & Coef. & $p$-value \\
\hline Intercept & 0.605 & 0.00 & 0.525 & 0.00 & 0.479 & 0.00 \\
\hline $\begin{array}{l}\text { Variable of interest } \\
\text { Premium }_{d-1} \\
\text { SCAR }_{d-1} \\
\text { Premium }_{d-1} \times \operatorname{SCAR}_{d-1}\end{array}$ & $\begin{array}{c}0.224 \\
-0.019 \\
0.169\end{array}$ & $\begin{array}{l}0.00 \\
0.16 \\
0.00\end{array}$ & $\begin{array}{c}0.099 \\
-0.017 \\
0.127\end{array}$ & $\begin{array}{l}0.04 \\
0.39 \\
0.02\end{array}$ & $\begin{array}{l}0.123 \\
0.003 \\
0.060\end{array}$ & $\begin{array}{l}0.04 \\
0.80 \\
0.06\end{array}$ \\
\hline Control variable & Yes & & Yes & & Yes & \\
\hline Marginal effect of SCAR & $4.27 \%$ & 0.04 & $4.54 \%$ & 0.08 & $2.89 \%$ & 0.09 \\
\hline $\begin{array}{l}\text { Number of observations } \\
\text { Adjusted- } R^{2} \\
F \text {-Statistic } \\
\end{array}$ & $\begin{array}{c}194 \\
26.81 \% \\
5.52 \\
\end{array}$ & & $\begin{array}{c}183 \\
19.59 \% \\
3.45 \\
\end{array}$ & & $\begin{array}{c}168 \\
15.68 \% \\
2.40 \\
\end{array}$ & \\
\hline \multicolumn{7}{|l|}{ Panel B. Sample selection } \\
\hline Independent variable & & Coefficient & & & $p$-value & \\
\hline Intercept & & 0.573 & & & 0.01 & \\
\hline $\begin{array}{l}\text { Variable of interest } \\
\text { Premium }_{d-1} \\
\text { SCAR }_{d-1} \\
\text { Premium }_{d-1} \times \operatorname{SCAR}_{d-1}\end{array}$ & & $\begin{array}{c}0.206 \\
-0.017 \\
0.170\end{array}$ & & & $\begin{array}{l}0.00 \\
0.14 \\
0.00\end{array}$ & \\
\hline Control variable & & Yes & & & & \\
\hline Heckman's Lambda & & -0.010 & & & 0.68 & \\
\hline Marginal effect of SCAR & & $4.40 \%$ & & & 0.03 & \\
\hline $\begin{array}{l}\text { Number of observations } \\
\text { Adjusted- } R^{2} \\
F \text {-Statistic }\end{array}$ & & $\begin{array}{c}186 \\
27.83 \% \\
5.10 \\
\end{array}$ & & & & \\
\hline
\end{tabular}


Panel C. Clustered standard errors

\begin{tabular}{|c|c|c|c|c|}
\hline Independent variable & \multicolumn{2}{|c|}{ Coefficient } & \multicolumn{2}{|c|}{$p$-value } \\
\hline Intercept & \multicolumn{2}{|c|}{0.605} & \multicolumn{2}{|c|}{0.09} \\
\hline \multicolumn{5}{|l|}{ Variable of interest } \\
\hline Premium $_{d-1}$ & \multicolumn{2}{|c|}{0.223} & \multicolumn{2}{|c|}{0.08} \\
\hline $\operatorname{SCAR}_{d-1}$ & \multicolumn{2}{|c|}{-0.018} & \multicolumn{2}{|c|}{0.19} \\
\hline 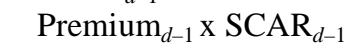 & \multicolumn{2}{|c|}{0.169} & \multicolumn{2}{|c|}{0.04} \\
\hline Control variable & \multicolumn{2}{|c|}{ Yes } & \\
\hline Marginal effect of SCAR & \multicolumn{2}{|c|}{$4.32 \%$} & & \\
\hline Number of observations & \multicolumn{2}{|c|}{194} & & \\
\hline Adjusted- $R^{2}$ & \multirow{2}{*}{\multicolumn{2}{|c|}{$\begin{array}{l}0.27 \\
5.07\end{array}$}} & & \\
\hline$F$-Statistic & & & & \\
\hline \multicolumn{5}{|c|}{ Panel D. Alternative time frames } \\
\hline \multirow[b]{2}{*}{ Independent variable } & \multicolumn{2}{|c|}{6 months time frame } & \multicolumn{2}{|c|}{24 months time frame } \\
\hline & Coef. & $p$-value & Coef. & $p$-value \\
\hline Intercept & 0.510 & 0.02 & 0.733 & 0.00 \\
\hline \multicolumn{5}{|l|}{ Variable of interest } \\
\hline Premium $_{d-1}$ & 0.338 & 0.00 & 0.220 & 0.00 \\
\hline $\mathrm{SCAR}_{d-1}$ & -0.051 & 0.05 & -0.039 & 0.01 \\
\hline Premium $_{d-1} \times \mathrm{SCAR}_{d-1}$ & 0.177 & 0.01 & 0.125 & 0.01 \\
\hline \multicolumn{5}{|l|}{ Control variable } \\
\hline Marginal effect of SCAR & $1.93 \%$ & 0.29 & $0.42 \%$ & 0.64 \\
\hline Number of observations & 106 & & 294 & \\
\hline Adjusted- $R^{2}$ & $35.17 \%$ & & $20.00 \%$ & \\
\hline$F$-Statistic & 3.84 & & 5.38 & \\
\hline
\end{tabular}

